\title{
Who Participates in the Skilled Technical Workforce After College and What Are Their Educational Pathways?
}

\author{
Xianglei Chen \\ RTI International
}

\begin{abstract}
The skilled technical workforce (STW) comprises workers in occupations that require significant science, technology, engineering, or mathematics (STEM) skills but not a bachelor's degree for entry. The United States had over 17 million STW workers in 2017, and is expected to be short about 3.4 million workers who are qualified for the available STW positions by 2022. Despite the important contribution of the STW to the U.S. economy, the policy discourse on the STEM workforce has largely focused on workers with bachelor's or graduate degrees, overlooking those without a 4-year degree. Consequently, knowledge about the STW is limited. This paper draws on a recently available national data source to provide a close look at STW workers through the lens of U.S. undergraduates who joined the STW after college. Multivariate results indicate that students who held STW jobs after college fared better than those who held nontechnical jobs on a range of employment outcomes, including salary, access to workforce benefits, alignment between college majors and intended careers, and job satisfaction. Multivariate analyses also confirmed that graduating from a less-than-4-year institution, earning a subbaccalaureate credential, and majoring in STEM, healthcare, and such technical fields as manufacturing, construction, repair, and transportation are common paths to STW careers. Despite the benefits of STW employment, however, relatively few students pursued STW jobs after college. Significantly fewer female than male students and fewer Black than White students pursued STW jobs, even after controlling for such factors as major field, type of last institution, STEM credits, and educational attainment. However, post-college STW participation did not differ between Hispanic and White students or vary by students' family income or their parents' education attainment.
\end{abstract}

Keywords: skilled technical workforce, STEM, technical career, undergraduate, school-to-work transition

The skilled technical workforce (STW) refers to workers in occupations that require significant science, technology, engineering, or mathematics (STEM) expertise but are not dependent on a bachelor's degree for entry. A handful of indicators suggests that workers without a bachelor's degree make up a considerable share of STEM employment in the United States. In 2011, one-fifth (26 million) of all U.S. jobs required substantial STEM skills, and half of these jobs did not require workers to have a 4-year degree (Rothwell, 2013). In 2015, almost 25 percent of STEM jobs were held by workers without a bachelor's degree (National Science Board [NSB], 2018a). The U.S. workforce had over 17 million STW workers in 2017, and 3.4 million STW jobs are expected to go

\footnotetext{
cc) (i) $\odot$ Creative Commons CC-BY-NC-ND: This article is distributed under the terms of the Creative Commons Attribution 4.0 License (http://creativecommons.org/licenses/by/4.0/) which allows others to download your works and share them
} with others as long as they credit you, but they can't change them in any way or use them commercially. 
unfilled by 2022 (NSB, 2019; NSB, 2020). Despite the important contribution of the STW to the U.S. economy, the policy discourse on the STEM workforce has largely focused on workers with bachelor's or graduate degrees, overlooking those without a 4year degree (NSB, 2015). As a result, there is not much data or research on the STW.

Recognizing the economic value of the STW, the NSB recently called for developing a strong STEM workforce that includes not only "traditional scientists and engineers performing research in university, government, or industry labs, but also skilled technical workers who can install, repair, debug, and build, but who do not have 4-year degrees" (NSB, 2018b, p. 2). In 2019, the NSB STW Task Force released a policy report, highlighting the urgent need to collect data to facilitate more research on the STW (NSB, 2019).

To fill the current information void on the STW and inform future research, this paper, along with an earlier article by Chen and Rotermund (2020), uses recently available national data from the 2012/17 Beginning Postsecondary Students Longitudinal Study (BPS:12/17) to provide a close look at STW workers through the lens of U.S. undergraduates who joined the STW after college. BPS:12/17 started with a nationally representative sample of undergraduates who entered college for the first time in the 2011-12 academic year. The study followed cohort members for 6 years, gathering information about their demographic backgrounds, enrollment experiences, degree completion, and employment during and after college. Although BPS:12/17 is not specifically designed to study STW issues (see data limitations in the Conclusions section), it has useful data elements that allow researchers to explore students' postcollege transitions into the STW and their preparation for STW careers. ${ }^{1}$ The earlier work of Chen and Rotermund (2020) provided a first glimpse into the rate at which undergraduates joined the STW within 6 years of college entry and compared the demographic composition and employment outcomes of those who held STW and nonSTW jobs. Drawing on newly available postsecondary transcript data collected for the BPS:12/17 cohort, this paper expands Chen and Rotermund's work to examine the postsecondary trajectories of STW workers and identify the demographic and educational factors uniquely associated with students' pursuit of STW careers.

The analysis in this paper is organized into four sections, each addressing one major research question. The first section looks at the prevalence of STW workers among recent undergraduates, addressing the question "What percentage of undergraduates joined the STW after college?"2 The second section describes the employment outcomes of those with STW jobs, answering the question "How do STW workers fare in the labor market compared with their non-STW peers?" This section extends Chen and Rotermund's earlier work with employment results from multivariate analyses. The third section addresses the question "What were STW workers' educational trajectories in college?" It presents a range of indicators with respect to students' enrollment

\footnotetext{
${ }^{1}$ BPS:12/17 cannot provide insights into the size or demand of the STW in the job market because it sampled students, not workers.

${ }^{2}$ To provide some context for analyses, the first two sections include some results that have appeared in the previous publication (Chen and Rotermund, 2020). These two sections also contain new analyses that provide more insights into STW employment.
} 
experiences, coursetaking, and attainment, providing insights into postsecondary pathways that prepare students for STW careers. The last section uses multivariate analysis to address the question "Which demographic and educational factors were uniquely associated with students pursuing STW careers after college?" The paper is descriptive and exploratory; its primary purpose is to provide an empirical look at the STW and generate baseline information for future research.

\section{Defining STW Jobs}

Although the definition of STW jobs is straightforward, i.e., highly technical jobs that do not require a bachelor's degree for entry, precisely identifying these jobs is difficult (Rothwell, 2016). Researchers have attempted to use wages, occupation characteristics, and education level to identify STW jobs (Autor et al., 2006; Holzer, 2015; National Research Council, 2014), but none of these approached have yielded sufficiently precise results. As noted by Rothwell (2016), defining STW jobs based on wages may undercount skilled workers who may experience downward wage trends as a result of market changes and overcount unskilled workers who are well paid merely because of factors unrelated to skills such as union contracts. Furthermore, identifying STW jobs based on education level may inadvertently include unskilled workers because the jobs with similar educational requirements may entail a broad range of skills.

To identify STW jobs with more precision, Rothwell (2016) suggested using information from the Department of Labor's Occupational Information Network $\left(\mathrm{O}^{*} \mathrm{NET}\right)$ to make a direct measure of the skills that jobs require. $\mathrm{O}^{*} \mathrm{NET}$ is the nation's primary source of occupational information. Through ongoing surveys of workers in each occupation, $\mathrm{O} * \mathrm{NET}$ gathers comprehensive information about the knowledge, training, skill, and educational requirements of each job in the U.S. market. The Knowledge Survey and Education and Training Survey are the two O*NET surveys that Rothwell used to identify STW jobs. The Knowledge Survey lays out 33 knowledge domains, asking workers to rate the level of each knowledge required to perform their jobs (Table 1). Using biology as an example, the Knowledge Survey asks workers, "What level of BIOLOGY knowledge is needed to perform your current job?" On a 1-7 scale, the survey provides anchors for the kinds of biology knowledge that would score a 1, 5, and 7: "Feeding domestic animals" would rate a 1, "Investigating the effects of pollution on marine plants and animals" would rate a 5, and "Isolating and identifying a new virus" would rate a 7. Based on workers' ratings, $\mathrm{O}^{*} \mathrm{NET}$ generates an average score of biology knowledge required for every occupation. The process is repeated for other knowledge domains; as a result, each occupation gets 33 average knowledge scores, each corresponding to one of the 33 knowledge domains.

The O*NET's Education and Training Survey gathers information about the level of education required for the job workers hold, and the survey response categories range from less than a high school diploma and high school diploma up to doctoral degree and post-doctoral training. 
Table 1. O*NET knowledge domains

\begin{tabular}{|c|c|}
\hline $\mathrm{O} *$ NET knowledge domain & $\begin{array}{l}\text { O*NET knowledge domains identified as technical by } \\
\text { Rothwell }\end{array}$ \\
\hline Biology & Yes \\
\hline Chemistry & Yes \\
\hline Physics & Yes \\
\hline Mathematics & Yes \\
\hline Engineering and Technology & Yes \\
\hline Computers and Electronics & Yes \\
\hline Economics and Accounting & Yes \\
\hline Production and Processing & Yes \\
\hline Food Production & Yes \\
\hline Design & Yes \\
\hline Building and Construction & Yes \\
\hline Mechanical & Yes \\
\hline Medicine and Dentistry & Yes \\
\hline Telecommunications & Yes \\
\hline Administration and Management & No \\
\hline Clerical & No \\
\hline Sales and Marketing & No \\
\hline Customer and Personal Service & No \\
\hline Personnel and Human Resources & No \\
\hline Psychology & No \\
\hline Sociology and Anthropology & No \\
\hline Geography & No \\
\hline Therapy and Counseling & No \\
\hline Education and Training & No \\
\hline English Language & No \\
\hline Foreign Language & No \\
\hline Fine Arts & No \\
\hline History and Archeology & No \\
\hline Philosophy and Theology & No \\
\hline Public Safety and Security & No \\
\hline Law and Government & No \\
\hline Communications and Media & No \\
\hline Transportation & No \\
\hline
\end{tabular}

Based on $\mathrm{O}^{*}$ NET knowledge and education survey data, Rothwell identified STW jobs in three steps. He first divided the 33 knowledge domains into two broad categories: technical and nontechnical. A total of 14 knowledge domains were deemed technical (Table 1). He then selected jobs that had an average O*NET knowledge score of 4.5 or higher in at least one of these 14 technical knowledge domains and considered these jobs highly technical. Finally, he defined a highly technical job as STW if most workers (more than 50 percent) in the job said that their job did not require a bachelor's degree. Although Rothwell's method is not perfect (e.g., workers' skill evaluations may be inconsistent and subjective), it has the advantage of categorizing jobs by skill requirements rather than the characteristics of workers (e.g., wages and education) in those jobs. After evaluating several definitions of STW jobs, the National Science Foundation chose Rothwell's method in a STW analysis included in the 2020 edition of Science and Engineering Indicators (NSB, 2020).

Likewise, this paper follows Rothwell's approach, identifying the STW jobs that BPS:12/17 students held that required high-level technical expertise (i.e., jobs with an average $\mathrm{O}^{*} \mathrm{NET}$ knowledge score of 4.5 or higher in at least one of the 14 technical knowledge domains) but did not require a bachelor's degree (i.e., jobs that less than 50 
percent of O*NET Education and Training Survey respondents said required a bachelor's degree). Examples of STW occupations include medical lab technicians, computer support specialists, and installers and machinists.

To provide analysis of the full range of technical occupations, the paper also examines jobs that require not only high-level technical expertise (i.e., jobs with an average $\mathrm{O}^{*} \mathrm{NET}$ knowledge score of 4.5 or higher in at least one of the 14 technical knowledge domains) but also a bachelor's degree (i.e., jobs that at least 50 percent of O*NET Education and Training Survey respondents said required a bachelor's degree). For convenience, these workers are referred to as the skilled professional workforce $(S P W)$ in the paper. Examples of SPW occupations include civil engineers, physicists, software developers, and biostatisticians.

For comparison purposes, the paper also includes the remaining occupations, i.e., those that fall in neither the STW nor the SPW, and refers to them as other jobs or nontechnical jobs interchangeably. Examples of these occupations include food preparation workers, social workers, English teachers, photographers, and artists.

\section{Data Source and Study Sample}

This paper draws on national data from BPS:12/17, a longitudinal study conducted by the U.S. Department of Education's (ED) National Center for Educational Statistics (NCES). BPS:12/17 targeted a nationally representative sample of first-time undergraduates who started college in 2011-12. These students were followed up twice: in 2014, about 3 years after their college entry; and in 2017, about 6 years after entry. Data were collected from multiple sources, including student interviews, sampled students' academic institutions, and such other relevant databases as ED records on federal student financial aid applications and federal student loan and grant programs and the Integrated Postsecondary Education Data System (IPEDS). Students' postsecondary transcripts were subsequently collected from all known institutions they have attended and released in December 2020.

About 22,500 2011-2012 beginning postsecondary students participated in the 2017 follow-up interview, which asked students about their employment history and enrollment status in January through June 2017. About 58 percent of students reported working and not enrolled in school during this period, 15 percent were both working and enrolled, and 27 percent were not working. Since BPS:12/17 has full employment data only on respondents' jobs in 2017 , the analyses in this paper were restricted to the 58 percent of students who were working but not in school in January through June $2017 .^{3}$ The paper excluded 27 percent of students who were not working in 2017 because of no employment data. The paper also excluded 15 percent of students who were working and also in school in 2017 because of the concern that the jobs these students held while enrolling in school may not be the jobs that they want to pursue after college.

\footnotetext{
${ }^{3}$ About 74 percent of these workers held full-time jobs and 26 percent held part-time jobs. To preserve statistical power, both groups were included in the analyses. Employment intensity was included as a control variable in subsequent multivariate analyses on employment outcomes.
} 
To assess whether restricting the analyses to the subsample of students who were working and not enrolled in 2017 resulted in any bias, table 2 compares the characteristics of these students with the characteristics of all BPS:12/17 sample members. Compared with the full sample, the sample selected for this paper had a higher share of students who were White (62 percent of the study sample vs. 57 percent of the full sample), who were in the third or higher immigrant generation ( 77 percent vs. 74 percent), who came from high-income backgrounds ( 28 percent vs. 25 percent), whose parents had attained a bachelor's or higher degree (42 percent vs. 40 percent), who last attended a private nonprofit 4-year institution (18 percent vs. 16 percent), and who had earned a bachelor's degree by 2017 (43 percent vs. 37 percent). Taken together, this study sample represents a subpopulation that is socioeconomically and academically advantaged relative to the entire population of 2011-12 beginning postsecondary students. This is likely due to excluding two groups of students from the study sample: those who were still in school 6 years after college entry and those who were out of school and unemployed. Research indicated that these two groups tended to have a higher share of students from disadvantaged socioeconomic and educational backgrounds (Chen et al., 2017; Pretlow et al., 2020).

Table 2. Selected characteristics of all 2011-12 beginning postsecondary students and of those who were working and not enrolled in 2017

\begin{tabular}{|c|c|c|}
\hline Characteristic & $\begin{array}{r}\text { All 2011-12 } \\
\text { beginning } \\
\text { postsecondary students } \\
(\%)\end{array}$ & $\begin{array}{r}2011-12 \text { beginning } \\
\text { postsecondary students who were } \\
\text { working and not enrolled in } 2017 \\
(\%)\end{array}$ \\
\hline Total & 100.0 & 100.0 \\
\hline \multicolumn{3}{|l|}{ Gender } \\
\hline Male & 43.5 & 44.3 \\
\hline Female & 56.5 & 55.7 \\
\hline \multicolumn{3}{|l|}{ Race/ethnicity } \\
\hline White & 56.8 & 61.9 \\
\hline Black & 14.1 & 11.9 \\
\hline Hispanic & 18.9 & 17.1 \\
\hline Asian & 5.2 & 4.3 \\
\hline Other & 4.9 & 4.9 \\
\hline \multicolumn{3}{|c|}{ Dependency status and family responsibilities in 2011-12 } \\
\hline Dependent & 78.3 & 80.6 \\
\hline Independent & 21.7 & 19.4 \\
\hline Unmarried, no dependent(s) & 7.7 & 7.1 \\
\hline Unmarried, with dependent(s) & 8.1 & 6.7 \\
\hline Married, no dependent(s) & 1.8 & 1.5 \\
\hline Married, with dependent(s) & 4.1 & 4.0 \\
\hline \multicolumn{3}{|l|}{ Immigrant generation } \\
\hline Immigrant & 7.4 & 6.0 \\
\hline Second-generation American & 18.6 & 17.3 \\
\hline Third- or higher-generation American & 74.0 & 76.7 \\
\hline \multicolumn{3}{|l|}{ Family income level } \\
\hline Lowest 25 percent & 25.1 & 21.8 \\
\hline Lower middle 25 percent & 24.9 & 24.0 \\
\hline Upper middle 25 percent & 25.1 & 26.4 \\
\hline Highest 25 percent & 24.9 & 27.8 \\
\hline
\end{tabular}




\begin{tabular}{|c|c|c|}
\hline \multicolumn{3}{|c|}{ Highest education attained by either parent } \\
\hline High school diploma or less & 32.2 & 29.7 \\
\hline Some postsecondary education & 27.7 & 28.0 \\
\hline Bachelor's or higher degree & 40.2 & 42.3 \\
\hline \multicolumn{3}{|l|}{ Control and level of last institution } \\
\hline Public 2-year & 32.3 & 32.9 \\
\hline Public 4-year & 35.5 & 35.0 \\
\hline Private nonprofit 4-year & 15.7 & 17.7 \\
\hline Private for-profit & 15.2 & 13.1 \\
\hline Other & 1.3 & 1.2 \\
\hline \multicolumn{3}{|c|}{ Highest postsecondary credential earned as of 2017} \\
\hline No credential earned & 43.9 & 39.5 \\
\hline Certificate & 8.5 & 8.0 \\
\hline Associate's degree & 10.9 & 9.1 \\
\hline Bachelor's degree & 36.8 & 43.4 \\
\hline
\end{tabular}

\section{Findings}

What Percentage of Undergraduates Joined the STW After College? Among BPS:12/17 cohort members who were working and not in school in 2017 (referred to as workers hereafter, for brevity), 9 percent were working in STW jobs, 16 percent were working in SPW jobs, and 75 percent were working in other jobs that did not require high-level technical expertise (Figure 1).

The percentage of students working in the STW jobs was higher for certificate and associate's degree earners and those who had not earned a postsecondary credential

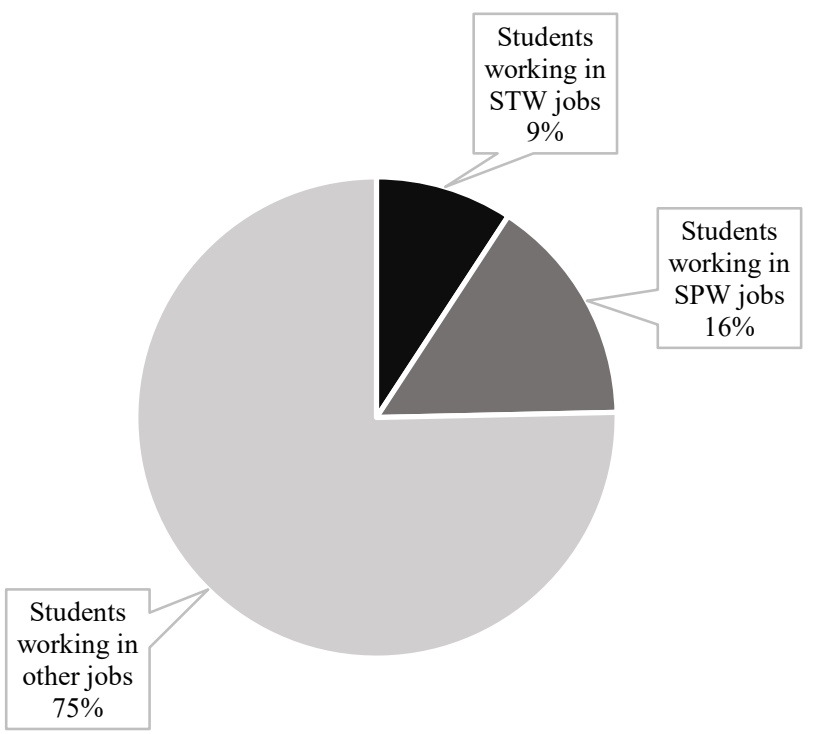

Figure 1. Among 2011-12 beginning postsecondary students who were working and not enrolled in 2017, percentage working in STW, SPW, and other jobs. 
Figure 2. Among 2011-12 beginning postsecondary students who were working and not enrolled in 2017, percentage working in STW jobs, by selected characteristics.

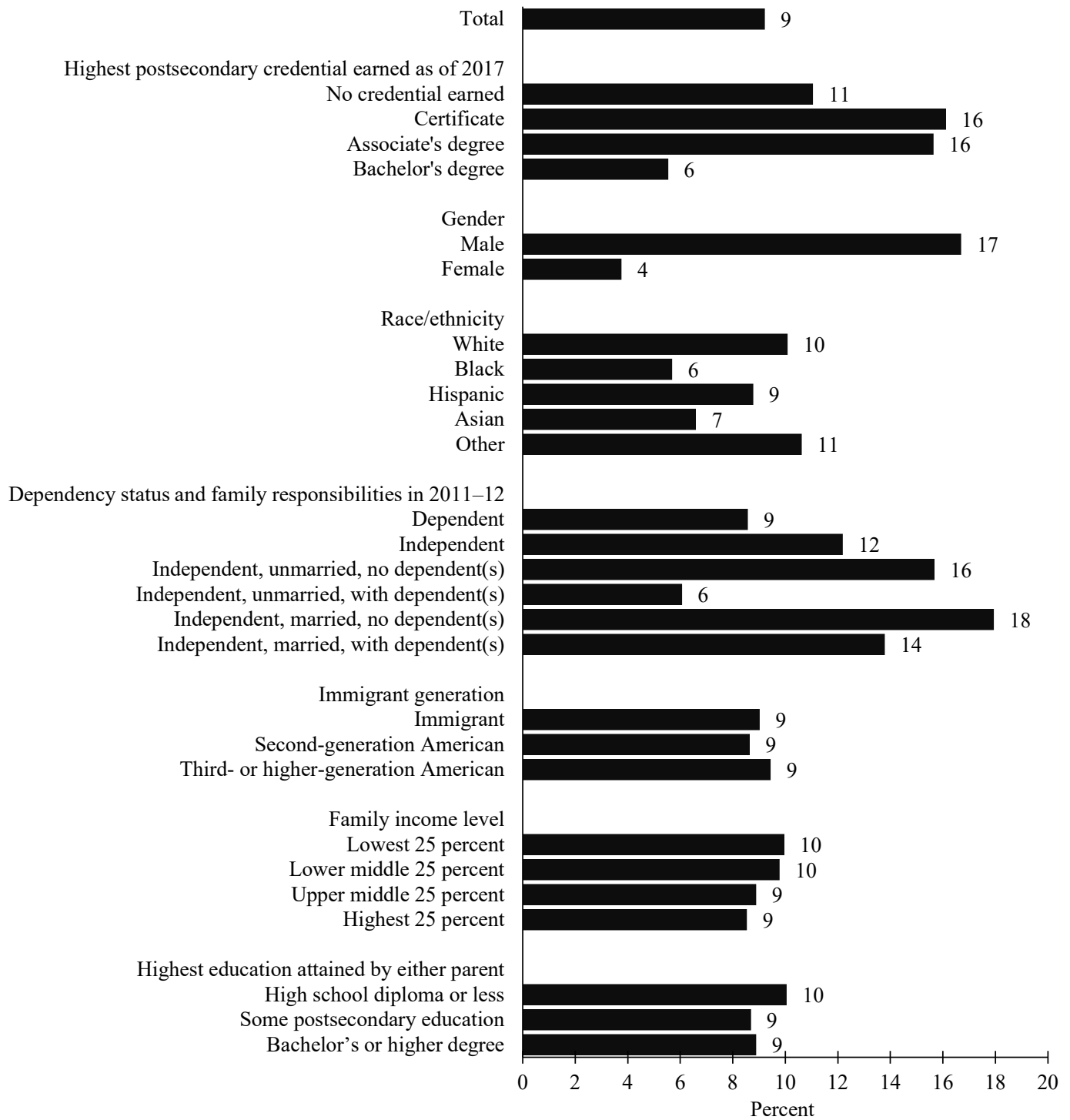

than for bachelor's degree earners (11-16 percent vs. 6 percent), for men than for women (17 percent vs. 4 percent), for White and Hispanic students than for Black students (9-10 percent vs. 6 percent), for independent students than for dependent students (12 percent vs. 9 percent), and for single or married independent students with no dependents than for single independent students with dependents (16-18 percent vs. 6 percent) (Figure 2). The rate of students working in STW jobs did not differ significantly by family income, parental education, and immigrant status. 
The vast majority of STW workers in the BPS:12/17 cohort (90 percent) were concentrated in six out of 23 broad occupation families: installation, maintenance, and repair occupations (30 percent); production occupations (18 percent); healthcare practitioners and technical occupations (14 percent); construction and extraction occupations (11 percent); computer and mathematical occupations ( 9 percent); and art, design, entertainment, sports, and media occupations (8 percent) (Table 3 ).

For comparison, the vast majority of SPW workers (92 percent) were found in six occupation families: business and financial operation occupations (20 percent); computer and mathematical occupations (19 percent); healthcare practitioners and technical occupations (16 percent); architecture and engineering occupations (15 percent); life, physical, and social science occupations (14 percent); and management occupations (8 percent).

Other non-STW and non-SPW workers were scattered in a diverse array of occupations, but several areas had relatively higher shares: office and administrative support occupations (19 percent); sales and related occupations (12 percent); education, training, and library occupations (10 percent); management occupations (9 percent); and food preparation and serving related occupations (8 percent).

Table 3. Occupations for STW, SPW, and other workers in the BPS:12/17 cohort.

\begin{tabular}{|c|c|c|c|}
\hline Occupation & $\begin{array}{r}\text { STW } \\
\text { workers }(\%) \\
\end{array}$ & $\begin{array}{r}\text { SPW } \\
\text { workers }(\%) \\
\end{array}$ & $\begin{array}{r}\text { Other } \\
\text { workers }(\%)\end{array}$ \\
\hline Total & 100.0 & 100.0 & 100.0 \\
\hline Installation, maintenance, and repair occupations & 29.7 & 0.0 & 0.4 \\
\hline Production occupations & 17.9 & 0.0 & 3.3 \\
\hline Healthcare practitioners and technical occupations & 14.2 & 15.8 & 2.1 \\
\hline Construction and extraction occupations & 10.9 & 0.0 & 1.1 \\
\hline Computer and mathematical occupations & 8.8 & 18.7 & 0.0 \\
\hline Art, design, entertainment, sports, and media occupations & 8.4 & 4.8 & 3.9 \\
\hline Architecture and engineering occupations & 5.1 & 15.0 & 0.0 \\
\hline Management occupations & 2.7 & 8.0 & 8.7 \\
\hline Life, physical, and social science occupations & 0.9 & 13.6 & 0.5 \\
\hline Business and financial operation occupations & 0.4 & 20.4 & 5.4 \\
\hline Sales and related occupations & 0.3 & 0.0 & 12.0 \\
\hline Farming, fishing, and forestry occupations & 0.2 & 0.1 & 0.3 \\
\hline Office and administrative support occupations & 0.2 & 0.1 & 18.6 \\
\hline Legal occupations & 0.1 & 0.0 & 1.5 \\
\hline Transportation and material moving occupations & 0.0 & 0.0 & 4.5 \\
\hline Community and social services occupations & 0.0 & 0.0 & 3.3 \\
\hline Education, training, and library occupations & 0.0 & 0.7 & 10.4 \\
\hline Healthcare support occupations & 0.0 & 0.0 & 5.9 \\
\hline Protective service occupations & 0.0 & 1.0 & 2.8 \\
\hline Food preparation and serving related occupations & 0.0 & 1.8 & 8.3 \\
\hline Building, grounds cleaning, and maintenance occupations & 0.0 & 0.0 & 1.6 \\
\hline Personal care and service occupations & 0.0 & 0.0 & 5.4 \\
\hline Military specific occupations & 0.0 & 0.0 & 0.3 \\
\hline
\end{tabular}

Note. The 23 broad occupation categories are based on the first two digits of a 6-digit code designated to each occupation in the 2010 Standard Occupational Classification (SOC). More information about the 2010 SOC is available at

https://www.bls.gov/soc/2010/2010_major_groups.htm 


\begin{tabular}{|c|c|c|c|c|c|}
\hline & $\begin{array}{r}\text { Median } \\
\text { annual salary (\$) }\end{array}$ & $\begin{array}{r}\text { Eligible } \\
\text { for health } \\
\text { insurance, } \\
\text { retirement } \\
\text { benefits, and life } \\
\text { insurance through } \\
2017 \text { job }(\%)\end{array}$ & $\begin{array}{r}2017 \\
\text { job was related to } \\
\text { college } \\
\text { majors } \\
(\%)\end{array}$ & $\begin{array}{r}2017 \\
\text { job was related to } \\
\text { intended future } \\
\text { careers } \\
(\%)\end{array}$ & $\begin{array}{r}\text { Satisfied } \\
\text { with } 2017 \text { job (\%) }\end{array}$ \\
\hline $\begin{array}{ll} & \text { All } \\
\text { workers } & \end{array}$ & 28,000 & 48.4 & 47.4 & 61.6 & 71.6 \\
\hline $\begin{array}{c}\text { STW } \\
\text { workers }\end{array}$ & 35,900 & 58.7 & 51.5 & 72.1 & 75.0 \\
\hline $\begin{array}{c}\text { SPW } \\
\text { workers }\end{array}$ & 47,900 & 71.8 & 81.7 & 89.8 & 82.2 \\
\hline $\begin{array}{r}\text { Other } \\
\text { workers }\end{array}$ & 25,000 & 44.3 & 41.1 & 56.5 & 69.0 \\
\hline
\end{tabular}

How Do STW Workers Fare in the Labor Market Compared with Their Non-STW Peers? STW workers fared better than nontechnical workers in the job market. The STW workers in the BPS:12/17 cohort earned a median salary of $\$ 35,900$, which was higher than the median salary of all workers $(\$ 28,000)$ and workers in nontechnical jobs $(\$ 25,000)$ (Table 4). STW workers were more likely than workers in nontechnical jobs to report that they were eligible for health insurance, retirement benefits, and life insurance through their jobs: 59 percent of STW workers were eligible for all these benefits, compared with 44 percent of workers in nontechnical jobs. More than half ( 52 percent) of STW workers, as opposed to 41 percent of workers in nontechnical jobs, reported that their job was related to their college majors. In addition, 72 percent of STW workers reported that their job was related to their intended future careers; in comparison, 57 percent of workers in nontechnical jobs indicated so. Finally, 75 percent of STW workers reported job satisfaction, which was higher than the 69 percent of workers in nontechnical jobs.

Employment outcomes of STW workers are less favorable when compared with SPW workers'. Nevertheless, it is important to point out that SPW jobs require a bachelor's degree for entry, and 81 percent of SPW workers in the BPS:12/17 cohort had earned a bachelor's degree, compared with just 29 percent of STW workers (Chen \& Rotermund, 2020).

The positive employment outcomes for STW workers relative to workers in nontechnical jobs may be due to a variety of factors that happen to covary with job category. For example, relatively more STW workers than nontechnical workers were full-time workers, 4 and full-time jobs usually provide higher salaries and better benefits. To disentangle the effects of such related factors, a multivariate analysis was conducted for each employment outcome examined in table 4. Depending on whether an outcome variable was continuous or dichotomous, either an ordinary-least-squares or logistic regression was run. The multivariate results in Table 5 indicate that even after controlling

\footnotetext{
${ }^{4}$ About 83 percent of STW workers and 89 percent of SPW workers in the BPS:12/17 cohort reported
} working full time in 2017, compared with 69 percent of other workers. 
Table 5. Coefficients from ordinary least squared (OLS) regression model predicting workers' annual salary and odds ratios from logistic regression models predicting selected employment outcomes of workers in the BPS:12/17 cohort.

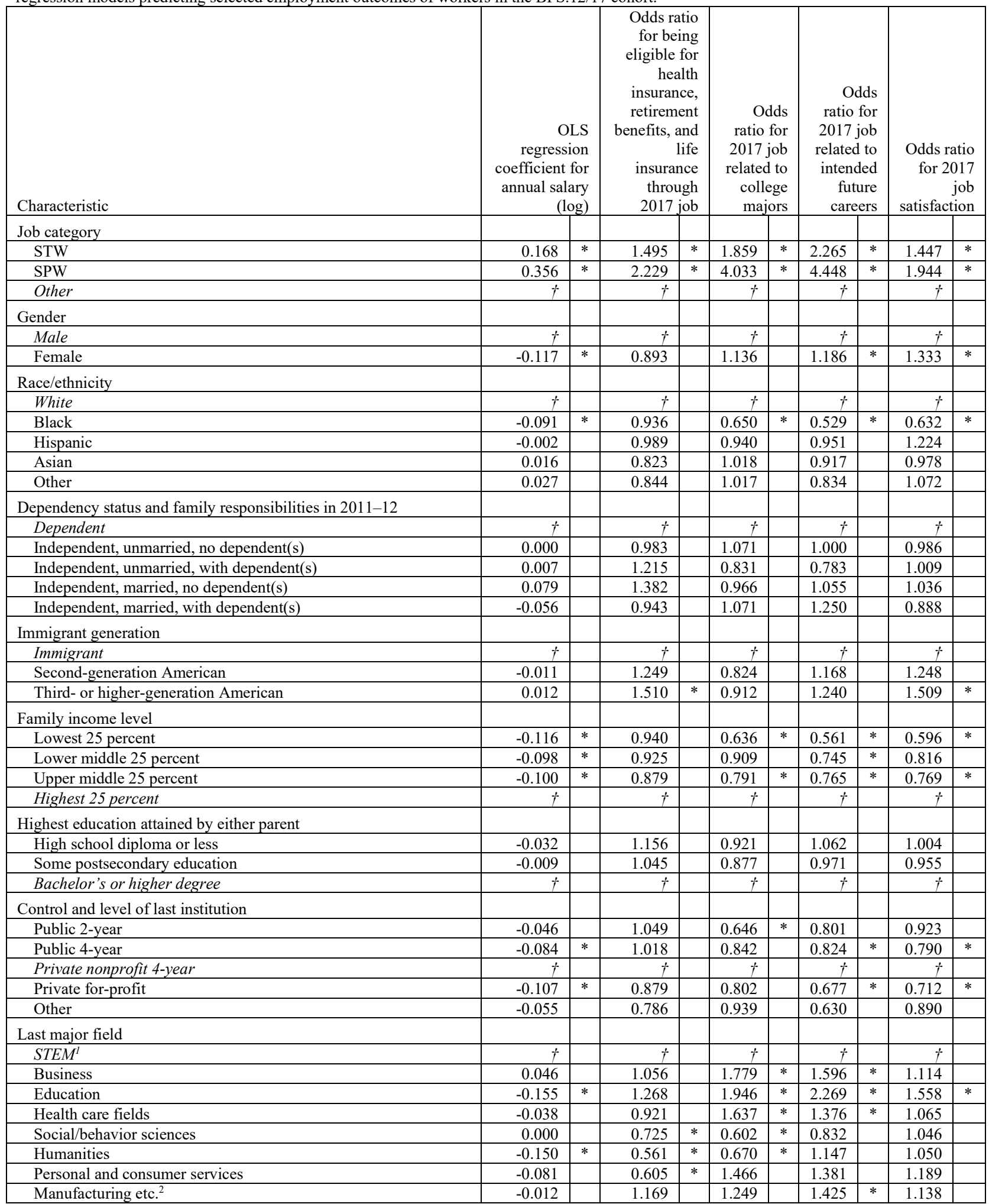




\begin{tabular}{|c|c|c|c|c|c|c|c|c|c|c|}
\hline Public, legal, and social services & -0.035 & & 1.112 & & 1.751 & * & 1.884 & $*$ & 1.192 & \\
\hline Architecture, design, and applied arts & -0.153 & $*$ & 0.902 & & 1.178 & & 1.300 & & 0.990 & \\
\hline Communications & 0.010 & & 0.970 & & 1.048 & & 1.552 & $*$ & 1.047 & \\
\hline General studies & -0.088 & & 0.992 & & 0.728 & & 1.046 & & 0.959 & \\
\hline Undeclared or undecided & -0.048 & & 0.937 & & $+\dagger$ & & 1.144 & & 0.904 & \\
\hline \multicolumn{11}{|c|}{ Highest postsecondary credential earned as of 2017} \\
\hline No credential earned & -0.122 & * & 0.753 & $*$ & 0.196 & * & 0.369 & * & 0.925 & \\
\hline Certificate & -0.070 & & 0.720 & & 0.677 & * & 0.791 & & 1.256 & \\
\hline Associate's degree & -0.083 & * & 0.785 & & 0.627 & * & 0.654 & * & 1.091 & \\
\hline Bachelor's degree & $t$ & & $t$ & & + & & $t$ & & $t$ & \\
\hline \multicolumn{11}{|l|}{ Employment intensity in 2017} \\
\hline Full time & 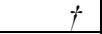 & & $t$ & & $\dagger$ & & $t$ & & $\dagger$ & \\
\hline Part time $^{3}$ & -0.858 & $*$ & 0.184 & $*$ & 0.643 & $*$ & 0.488 & $*$ & 0.747 & $*$ \\
\hline \multicolumn{11}{|l|}{ Years worked in same or similar job } \\
\hline Less than 1 year & -0.020 & & 1.094 & & 0.858 & & 0.858 & & 0.885 & \\
\hline 1 year & 0.056 & & 1.272 & & 1.151 & & 1.191 & & 1.095 & \\
\hline 2 years & 0.001 & & 1.227 & & 1.439 & * & 1.218 & & 1.057 & \\
\hline 3 or more years & $t$ & & $t$ & & $t$ & & $t$ & & $t$ & \\
\hline $\begin{array}{l}\dagger \text { Not applicable because the italic catego } \\
\dagger \dagger \text { The question was not asked to student } \\
*=\mathrm{p}<.05 \text {. } \\
{ }^{1} \text { Includes majors in mathematics, biologi } \\
\text { computer/information sciences. } \\
{ }^{2} \text { Includes majors in manufacturing, const } \\
{ }^{3} \text { Part-time employment refers to working }\end{array}$ & \multicolumn{10}{|c|}{$\begin{array}{l}\text { † Not applicable because the italic category is a comparison group in the variable. } \\
\text { †† The question was not asked to students who did not declare or decide the last major. } \\
*=\mathrm{p}<.05 \text {. }\end{array}$} \\
\hline
\end{tabular}

for demographic characteristics, major field, type of last institution attended, highest educational attainment, job intensity, and work experience, STW workers still had better employment outcomes than other nontechnical workers with respect to salary, access to workforce benefits, major-job alignment, and job satisfaction.

What Were STW Workers' Educational Trajectories in College? Given the positive employment outcomes that accompany STW jobs, it is important to examine the educational trajectories that lead students to STW careers. Understanding the postsecondary pathways of STW workers may offer insights for students on how to move through college to STW careers more efficiently and avoid various pitfalls that delay progress. This section examines a range of indicators that inform the postsecondary paths that STW workers in the BPS:12/17 cohort took in college. These indicators include the type of first and last institution, first and last degree program, first and last major field, enrollment continuation and disruption, coursetaking in STEM and career and technical education (CTE) subjects, type and level of postsecondary credential earned, and time to degree. For comparison purpose, the results of SPW and other workers are also included.

Enrollment characteristics. More than half of STW workers (52 percent) began postsecondary education at a 2-year or less-than-2-year institution, with 40 percent starting at a public 2-year institution (Table 6). In comparison, the majority of SPW workers ( 82 percent) and most of other workers ( 57 percent) began their college education at a 4-year institution. Reflecting the type of institution initially attended, nearly 60 percent of STW workers first enrolled in a sub baccalaureate program. In contrast, 79 percent of SPW workers and 51 percent of other workers first enrolled in a bachelor's degree program. In terms of first major field, significantly more STW and 
Table 6. Percentage distribution of STW, SPW, and other workers in the BPS:12/17 cohort with selected initial enrollment characteristics.

\begin{tabular}{|c|c|c|c|}
\hline Initial enrollment characteristics & $\begin{array}{r}\text { STW } \\
\text { workers }\end{array}$ & $\begin{array}{r}\text { SPW } \\
\text { workers }\end{array}$ & $\begin{array}{r}\text { Other } \\
\text { workers }\end{array}$ \\
\hline \multicolumn{4}{|l|}{ Level of first institution } \\
\hline 4-year & 48.5 & 81.9 & 57.0 \\
\hline 2-year & 47.5 & 17.4 & 39.7 \\
\hline Less than 2-year & 4.0 & 0.7 & 3.2 \\
\hline \multicolumn{4}{|l|}{ Control and level of first institution } \\
\hline Public 2-year & 39.7 & 16.6 & 35.3 \\
\hline Public 4-year & 29.9 & 48.0 & 33.7 \\
\hline Private nonprofit 4-year & 13.1 & 30.9 & 18.8 \\
\hline Private for-profit & 12.9 & 4.4 & 11.2 \\
\hline Other & 4.3 & 0.2 & 1.0 \\
\hline \multicolumn{4}{|l|}{ First degree program } \\
\hline No degree program & 1.3 & 0.4 & 1.5 \\
\hline Sub baccalaureate credential program & 58.5 & 20.3 & 47.6 \\
\hline Certificate & 13.2 & 2.1 & 8.3 \\
\hline Associate's degree & 45.3 & 18.2 & 39.3 \\
\hline Bachelor's degree & 40.2 & 79.3 & 51.0 \\
\hline \multicolumn{4}{|l|}{ First major field } \\
\hline STEM $^{1}$ & 29.2 & 34.5 & 14.3 \\
\hline Business & 8.2 & 16.6 & 13.6 \\
\hline Education & 1.6 & 2.3 & 7.0 \\
\hline Health care fields & 10.3 & 16.0 & 16.1 \\
\hline Social/behavior sciences & 3.5 & 5.8 & 8.9 \\
\hline Humanities & 5.3 & 4.4 & 7.9 \\
\hline Personal and consumer services & 3.1 & 2.7 & 4.4 \\
\hline Manufacturing etc. $^{2}$ & 19.7 & 2.0 & 5.9 \\
\hline Public, legal, and social services & 0.8 & 0.4 & 2.6 \\
\hline Architecture, design, and applied arts & 2.3 & 4.0 & 1.8 \\
\hline Communications & 2.0 & 1.6 & 3.2 \\
\hline General studies & 9.9 & 5.5 & 9.1 \\
\hline Undecided or undeclared & 4.1 & 4.2 & 5.0 \\
\hline
\end{tabular}

SPW workers than other workers chose a STEM major at the start (29 percent and 35 percent vs. 14 percent, respectively), and significantly more STW workers than SPW and other workers chose their first major in manufacturing, construction, repair, transportation, military technology, and protective services ( 20 percent vs. 2 percent and 6 percent, respectively).

The enrollment patterns of STW workers at the end of their college careers largely resembled those at the beginning (Table 7). Most STW workers (53 percent) last attended a 2-year or less-than-2-year institution, including 41 percent who last attended a public 2-year institution. In contrast, 84 percent of SPW workers and 59 percent of other workers last attended a 4-year institution. Significantly more STW workers than SPW workers were last enrolled in a sub baccalaureate program (37 percent vs. 11 percent) and significantly fewer STW workers than SPW and other workers were last enrolled in a bachelor's degree program (53 percent vs. 83 percent and 61 percent, respectively). In terms of last major, significantly more STW and SPW workers than other workers ended with a STEM field (29 percent and 37 percent vs. 13 percent, respectively), and significantly more STW workers than SPW and other workers ended with a field in 
Table 7. Percentage distribution of STW, SPW, and other workers in the BPS:12/17 cohort with selected last enrollment characteristics.

\begin{tabular}{|c|c|c|c|}
\hline Last enrollment characteristics & $\begin{array}{r}\text { STW } \\
\text { workers }\end{array}$ & $\begin{array}{r}\text { SPW } \\
\text { workers }\end{array}$ & $\begin{array}{r}\text { Other } \\
\text { workers }\end{array}$ \\
\hline \multicolumn{4}{|l|}{ Level of last institution } \\
\hline 4-year & 47.2 & 83.7 & 59.1 \\
\hline 2-year & 49.5 & 15.6 & 37.2 \\
\hline Less than 2-year & 3.2 & 0.7 & 3.8 \\
\hline \multicolumn{4}{|c|}{ Control and level of last institution } \\
\hline Public 2-year & 40.9 & 14.7 & 32.3 \\
\hline Public 4-year & 30.3 & 50.8 & 35.5 \\
\hline Private nonprofit 4-year & 10.4 & 29.2 & 17.7 \\
\hline Private for-profit & 15.1 & 5.2 & 13.4 \\
\hline Other & 3.3 & 0.2 & 1.1 \\
\hline \multicolumn{4}{|l|}{ Last degree program } \\
\hline No degree program & 9.3 & 6.1 & 6.8 \\
\hline Sub baccalaureate credential program & 37.4 & 10.7 & 31.8 \\
\hline Certificate & 10.1 & 2.2 & 10.2 \\
\hline Associate's degree & 27.2 & 8.5 & 21.6 \\
\hline Bachelor's degree & 53.4 & 83.3 & 61.4 \\
\hline \multicolumn{4}{|l|}{ Last major field } \\
\hline STEM $^{1}$ & 28.7 & 36.9 & 13.1 \\
\hline Business & 6.8 & 19.3 & 15.2 \\
\hline Education & 0.7 & 1.6 & 6.1 \\
\hline Health care fields & 11.9 & 16.2 & 13.2 \\
\hline Social/behavior sciences & 2.5 & 7.3 & 10.4 \\
\hline Humanities & 6.2 & 3.0 & 9.1 \\
\hline Personal and consumer services & 4.3 & 2.3 & 4.5 \\
\hline Manufacturing etc. $^{2}$ & 17.9 & 1.5 & 6.0 \\
\hline Public, legal, and social services & 1.2 & 0.6 & 3.1 \\
\hline Architecture, design, and applied arts & 2.4 & 4.4 & 1.3 \\
\hline Communications & 2.7 & 2.1 & 4.3 \\
\hline General studies & 6.2 & 2.3 & 6.6 \\
\hline Undecided or undeclared & 8.5 & 2.5 & 7.1 \\
\hline
\end{tabular}

manufacturing, construction, repair, transportation, military technology, or protective services (18 percent vs. 2 percent and 6 percent, respectively).

Attending school part time, halting enrollment for a period of time, and changing major fields make the path to college completion less efficient. While in college, STW and other workers were more likely than SPW workers to attend school only part time (13 percent and 10 percent vs. 3 percent, respectively), interrupt their enrollment with a break of 5 or more months (32 percent and 29 percent vs. 11 percent, respectively), and transfer between schools (31 percent and 26 percent vs. 22 percent) (Table 8). About 41 percent of STW workers changed their majors at least once and 15 percent changed their majors multiple times, although relatively more SPW and other workers did so than STW workers.

STEM and CTE coursetaking. Given that STW workers apply substantial STEM knowledge in their jobs, it is important to look at their STEM preparation in college. The analysis also included CTE coursetaking because most CTE programs have STEM components, are offered at the sub baccalaureate level, and aim to prepare students for a 
Table 8. Percentage of STW, SPW, and other workers in the BPS:12/17 cohort with selected enrollment characteristics through college.

\begin{tabular}{|c|c|c|c|}
\hline Enrollment characteristics through college & $\begin{array}{r}\text { STW } \\
\text { workers }\end{array}$ & $\begin{array}{r}\text { SPW } \\
\text { workers }\end{array}$ & $\begin{array}{r}\text { Othe } \\
\mathrm{r} \\
\text { workers }\end{array}$ \\
\hline \multicolumn{4}{|l|}{ Attendance intensity through 2017} \\
\hline Always full time & 34.4 & 42.0 & 32.9 \\
\hline Always part time & 12.8 & 2.7 & 10.3 \\
\hline Mixed & 52.8 & 55.3 & 56.8 \\
\hline Had at least one stopout through $2017^{1}$ & 31.6 & 11.2 & 28.7 \\
\hline Only one time & 25.2 & 9.0 & 22.2 \\
\hline Two or more times & 6.4 & 2.2 & 6.5 \\
\hline $\begin{array}{l}\text { Transferred between institutions at least one } \\
\text { time through } 2017^{2}\end{array}$ & 30.5 & 21.5 & 26.4 \\
\hline Only one time & 26.5 & 19.2 & 22.4 \\
\hline Two or more times & 4.0 & 2.3 & 4.0 \\
\hline $\begin{array}{l}\text { Changed major field at least one time } \\
\text { through } 2017^{3}\end{array}$ & 40.7 & 57.0 & 49.5 \\
\hline Only one time & 25.3 & 32.4 & 28.6 \\
\hline Two or more times & 15.4 & 24.5 & 21.0 \\
\hline
\end{tabular}

${ }^{1}$ A stopout refers to a break in enrollment of five or more consecutive months.

${ }^{2} \mathrm{~A}$ transfer occurs when a student left one institution and enrolled at another institution for four or more months consecutively. Students who co-enrolled in two institutions are not considered to be transfers.

${ }^{3}$ Students who never enrolled in a degree program or declare a major field are considered not changing their major field through 2017.

Table 9. STEM and CTE credits earned by STW, SPW, and other workers in the BPS:12/17 cohort, by highest postsecondary credential earned.

\begin{tabular}{|c|c|c|c|c|}
\hline & \multicolumn{2}{|c|}{ STEM $^{1}$} & \multicolumn{2}{|r|}{$\mathrm{CTE}^{2}$} \\
\hline Highest postsecondary credential earned & $\begin{array}{r}\text { Percen } \\
\text { t who earned any } \\
\text { STEM credits } \\
\text { through } 2017 \\
\end{array}$ & $\begin{array}{r}\text { Averag } \\
\text { e number of } \\
\text { STEM credits } \\
\text { earned }^{3} \\
\end{array}$ & $\begin{array}{r}\text { Perce } \\
\text { nt who earned } \\
\text { any CTE credits } \\
\text { through } 2017 \\
\end{array}$ & $\begin{array}{r}\text { Averag } \\
\text { e number of CTE } \\
\text { credits earned }^{3}\end{array}$ \\
\hline Total & 82.9 & 24.2 & 35.7 & 18.8 \\
\hline STW workers & 83.3 & 25.1 & 47.5 & 26.0 \\
\hline SPW workers & 95.1 & 46.9 & 22.1 & 19.7 \\
\hline Other workers & 82.9 & 19.9 & 35.7 & 17.8 \\
\hline \multicolumn{5}{|l|}{ No credential earned } \\
\hline STW workers & 69.8 & 12.2 & 45.2 & 15.6 \\
\hline SPW workers & 71.2 & 16.2 & 47.6 & 11.0 \\
\hline Other workers & 66.1 & 11.2 & 43.2 & 9.9 \\
\hline \multicolumn{5}{|l|}{ Highest credential earned was certificate } \\
\hline STW workers & 71.5 & 10.7 & 85.8 & 36.3 \\
\hline SPW workers & 75.2 & 9.5 & 77.5 & 32.2 \\
\hline Other workers & 59.2 & 10.8 & 70.6 & 26.5 \\
\hline \multicolumn{5}{|l|}{$\begin{array}{l}\text { Highest credential earned was associate's } \\
\text { degree }\end{array}$} \\
\hline STW workers & 94.6 & 20.4 & 82.3 & 36.6 \\
\hline SPW workers & 93.2 & 31.8 & 76.9 & 41.8 \\
\hline Other workers & 91.4 & 22.3 & 75.9 & 35.1 \\
\hline \multicolumn{5}{|l|}{$\begin{array}{l}\text { Highest credential earned was bachelor's } \\
\text { degree }\end{array}$} \\
\hline STW workers & 97.8 & 42.7 & 17.6 & 13.9 \\
\hline SPW workers & 98.1 & 50.9 & 14.2 & 12.4 \\
\hline Other workers & 96.7 & 24.6 & 16.7 & 10.9 \\
\hline
\end{tabular}

${ }^{1}$ STEM credits are the sum of the credits earned in mathematics, biological/life sciences, physical sciences, science technologies, engineering/engineering technologies, and computer/information sciences. 


\begin{abstract}
${ }^{2} \mathrm{CTE}$ credits are the sum of the credits earned in following areas: agriculture, agriculture operations, and related services; natural resources and conservation; communication, journalism, and related programs; communications technologies and support services; computer and information sciences and support services; personal and culinary services; education; engineering, engineering technologies, and engineering-related fields; family and consumer sciences and human sciences; legal professions and studies; library science; military technologies and applied sciences; parks, recreation, and leisure studies; theology and religious vocations; science and technologies; homeland security, law enforcement, firefighting and related protective services; public administration and social service professions; design; health professions and related programs; and business, management, marketing, and related support services.

${ }^{3}$ Average number of STEM or CTE credits earned was estimated for those who had earned STEM or CTE credits through 2017.
\end{abstract}

wide range of occupations including those that do not require a 4-year degree (Levesque et al., 2008). STEM coursetaking was widespread: 83 percent of STW workers, 95 percent of SPW workers, and 83 percent of other workers earned some STEM credits while in college (Table 9). Judging by the number of STEM credits earned, SPW workers took more STEM courses than STW workers, and both groups took more STEM courses than other workers. Data disaggregated by the highest credential earned further revealed that STEM coursetaking was more prevalent among bachelor's and associate's degree earners than among certificate earners and those who did not earn any credential, regardless of job category.

CTE coursetaking was not as widespread as STEM coursetaking. Overall, 36 percent of workers in the BPS:12/17 cohort had earned some CTE credits, compared with 83 percent of workers who had earned some STEM credits. CTE coursetaking was more prevalent among STW workers than among SPW and other workers: 48 percent of STW workers, 22 percent of SPW workers, and 36 percent of other workers earned CTE credits while in college. Disaggregating by the highest credential earned, CTE coursetaking was more widespread among certificate and associate's degree earners than among bachelor's degree earners, regardless of job category.

Type of postsecondary credentials attained. Forty-two percent of STW workers in the BPS 12/17 cohort had not completed any degree or certificate (Table 10). The remaining 58 percent of STW workers were evenly split between students who earned sub baccalaureate awards (29 percent) and those who earned bachelor's degrees (29 percent). Relatively fewer SPW workers (11 percent) had not completed a degree or certificate, and most ( 81 percent) had completed a bachelor's degree. Other workers fell in the middle: 39 percent had not completed a credential, and 44 percent had completed a bachelor's degree.

Looking at the types of credentials earned, 6-10 percent of STW, SPW, and other workers had earned two or more different types of credentials (e.g., certificate plus associate's degree, associate's degree plus bachelor's degree). Relatively more STW workers than SPW and other workers had earned only certificates or only associate's degrees, whereas relatively more SPW workers than STW and other workers had earned only bachelor's degrees.

Time to degree. Data on time to degree suggests that STW workers completed their associate's degrees faster than SPW and other workers did. Looking at those whose highest credential as of 2017 was an associate's degree, STW workers spent an average of 27 months to complete that degree, whereas SPW and other workers spent an average of 36-37 months to complete (Table 11). Looking at those who had earned only an 
Table 10. Percentage of STW, SPW, and other workers in the BPS:12/17 cohort with various levels and types of postsecondary

\begin{tabular}{|c|c|c|c|}
\hline Postsecondary attainment & $\begin{array}{r}\text { STW } \\
\text { workers }\end{array}$ & $\begin{array}{r}\text { SPW } \\
\text { workers }\end{array}$ & $\begin{array}{r}\text { Other } \\
\text { workers }\end{array}$ \\
\hline \multicolumn{4}{|l|}{ Highest postsecondary credential earned as of 2017} \\
\hline No credential earned & $\begin{array}{r}42 . \\
2\end{array}$ & 11.1 & 39.3 \\
\hline Sub baccalaureate credential & $\begin{array}{r}29 . \\
0\end{array}$ & 7.9 & 17.2 \\
\hline Certificate & $\begin{array}{r}13 . \\
4\end{array}$ & 1.4 & 8.2 \\
\hline Associate's degree & $\begin{array}{r}15 . \\
7\end{array}$ & 6.5 & 9.0 \\
\hline Bachelor's degree & $\begin{array}{r}28 . \\
8 \\
\end{array}$ & 81.0 & 43.5 \\
\hline \multicolumn{4}{|l|}{ Type of postsecondary credential earned as of 2017} \\
\hline No credential earned & $\begin{array}{r}42 . \\
2 \\
\end{array}$ & 11.1 & 39.3 \\
\hline Only certificate & $\begin{array}{r}13 . \\
4\end{array}$ & 1.4 & 8.2 \\
\hline Only associate's degree & $\begin{array}{r}10 . \\
9\end{array}$ & 4.5 & 7.2 \\
\hline Only bachelor's degree & $\begin{array}{r}23 . \\
2\end{array}$ & 73.6 & 38.7 \\
\hline Associate's degree plus certificate & 4.8 & 2.1 & 1.8 \\
\hline Bachelor's degree plus certificate and/or associate's degree & 5.6 & 7.4 & 4.8 \\
\hline
\end{tabular}

Table 11. Time to degree for STW, SPW, and other workers in the BPS:12/17 cohort who had earned a postsecondary credential by 2017.

\begin{tabular}{|c|c|c|c|}
\hline Time to degree & $\begin{array}{r}\text { STW } \\
\text { workers }\end{array}$ & $\begin{array}{r}\text { SPW } \\
\text { workers }\end{array}$ & $\begin{array}{r}\text { Other } \\
\text { workers }\end{array}$ \\
\hline \multicolumn{4}{|c|}{$\begin{array}{l}\text { Average number of months elapsed between postsecondary entry and } \\
\text { highest postsecondary credential receipt }\end{array}$} \\
\hline Highest credential earned was certificate & 16.6 & 14.0 & 16.1 \\
\hline Highest credential earned was associate's degree & 26.8 & 36.7 & 35.5 \\
\hline Highest credential earned was bachelor's degree & 44.6 & 45.2 & 44.1 \\
\hline \multicolumn{4}{|c|}{$\begin{array}{l}\text { Among students who earned only one postsecondary credential as of } \\
\text { 2017, average number of months elapsed between postsecondary entry } \\
\text { and credential receipt }\end{array}$} \\
\hline Credential earned was certificate & 16.8 & 13.5 & 16.3 \\
\hline Credential earned was associate's degree & 27.2 & 33.8 & 35.0 \\
\hline Credential earned was bachelor's degree & 47.1 & 46.5 & 45.8 \\
\hline
\end{tabular}

associate's degree, STW workers took an average of 27 months to complete the associate's degree, compared with 34-35 months taken by SPW and other workers.

Which Demographic and Educational Factors Were Uniquely Associated with Students Pursuing STW Careers After College? To better understand the relationship of various characteristics with the outcome of interest, this section presents the results of a multivariate analysis that examines how each demographic and educational characteristic was independently associated with students pursuing STW jobs 
after college, while controlling for other characteristics. It is important to note that this multivariate analysis is not designed to verify a theory or confirm any causal relationships. The purpose of this analysis is to refine bivariate analyses, and more specifically, to examine the strength of associations between various characteristics and STW participation while taking into account the interrelationships of these characteristics.

This multivariate analysis focuses on the outcome variable that has three distinctive categories that describe whether a student was working in a STW, SPW, or non-STW and non-SPW job in 2017. The outcome of "working in a STW job" is the primary interest. To examine the association of these multiple discrete outcomes with various characteristics, this paper employed a multinomial probit (MNP) model, which is one of the most common statistical techniques used to estimate the probability of a respondent choosing or achieving a certain outcome among several mutually exclusive outcomes (Borooah, 2001). ${ }^{5}$

To explore the association of the outcome of interest with various characteristics, the MNP regression model included most of the demographic and educational characteristics examined above as independent variables: gender, race/ethnicity, dependency status and family responsibilities, immigrant generation, family income, parental education, enrollment intensity, stopout, major change, school transfer, STEM credits, CTE credits, last major field, type of last institution, and type of postsecondary credentials earned. ${ }^{6}$ The selection of these independent variables was not based on any theory; the goal was to explore the nature of the relationships and provide initial empirical results for future research.

Table 12 presents the MNP regression results for the outcomes of "working in a STW job" and "working in a SPW job", with the outcome of "working in other non-STW and non-SPW jobs" as the comparison category. The marginal effect (ME) represents the percentage point change in the predicted probability of achieving an outcome associated with a one-unit change in an independent variable, while holding constant other independent variables in the model. A significant ME (marked by an asterisk) indicates that the change in the predicted probability is significantly different from zero. Using the independent variable "gender" as an example, the ME for "females" associated with working in STW jobs was -10.7; this means that the predicted probability of working in STW jobs after college changed by -10.7 percentage points when the independent variable "gender" changed one unit from male to female (male coded as " 0 " and female coded as "1"). In other words, the predicted probability of pursing STW jobs after college for female students is 10.7 percentage points lower than that for male students when

\footnotetext{
${ }^{5}$ This paper used a probit rather than a logit model because probit models do not require independence of irrelevant alternatives (IIA), an assumption that the preferences between outcomes A and B rely only on the individual preferences between $\mathrm{A}$ and $\mathrm{B}$ and do not change after introducing $\mathrm{C}$. An MNP model relaxes this assumption, allowing more flexibility in model specifications.

${ }^{6}$ The MNP regression model did not include first major field, control and level of first institution, and first and last degree program because these variables had high correlations with one or more independent variables included in the model.
} 


\section{Chen: Undergraduates Who Join the Skilled Technical Workforce After College}

Table 12. Marginal effects of various characteristics on the probability of students working in STW and SPW jobs after college, and the predicted probability of working in STW and SPW jobs for students with various characteristics.

\begin{tabular}{|c|c|c|c|c|c|c|}
\hline \multirow[b]{2}{*}{ Characteristic } & \multicolumn{3}{|c|}{ Working in a STW job } & \multicolumn{3}{|c|}{ Working a SPW job } \\
\hline & $\begin{array}{r}\text { Marginal } \\
\text { effect } \\
(\mathrm{ME})\end{array}$ & $\begin{array}{r}\text { Predicted } \\
\text { probability } \\
(\mathrm{PP}) \text { in } \%\end{array}$ & & $\begin{array}{r}\text { Marginal } \\
\text { effect } \\
(\mathrm{ME}) \\
\end{array}$ & $\begin{array}{r}\text { Predicted } \\
\text { probability } \\
(\mathrm{PP}) \text { in \% }\end{array}$ & \\
\hline \multicolumn{7}{|l|}{ Gender } \\
\hline Male & 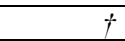 & 15.1 & & $t$ & 18.8 & \\
\hline Female & -10.7 & 4.4 & $*$ & -5.8 & 13.0 & $*$ \\
\hline \multicolumn{7}{|l|}{ Race/ethnicity } \\
\hline White & + & 10.1 & & + & 16.2 & \\
\hline Black & -4.2 & 5.9 & $*$ & -3.0 & 13.1 & $*$ \\
\hline Hispanic & -1.6 & 8.6 & & -3.2 & 13.0 & $*$ \\
\hline Asian & -2.4 & 7.7 & & 0.1 & 16.3 & \\
\hline Other & -0.2 & 9.9 & & -0.6 & 15.5 & \\
\hline \multicolumn{7}{|c|}{ Dependency status and family responsibilities in 2011-12 } \\
\hline Dependent & $t$ & 9.1 & & $t$ & 15.4 & \\
\hline Independent, unmarried, no dependent(s) & 1.5 & 10.6 & & 1.5 & 16.9 & \\
\hline Independent, unmarried, with dependent(s) & -2.6 & 6.5 & & -2.8 & 12.6 & \\
\hline Independent, married, no dependent(s) & 1.7 & 10.8 & & 8.7 & 24.1 & \\
\hline Independent, married, with dependent(s) & 2.1 & 11.3 & & -2.2 & 13.3 & \\
\hline \multicolumn{7}{|l|}{ Immigrant generation } \\
\hline Immigrant & + & 9.2 & & + & 16.4 & \\
\hline Second-generation American & 0.1 & 9.3 & & -1.9 & 14.5 & \\
\hline Third- or higher-generation American & 0.1 & 9.3 & & -0.9 & 15.5 & \\
\hline \multicolumn{7}{|l|}{ Family income level } \\
\hline Lowest 25 percent & 1.2 & 10.0 & & -2.9 & 13.5 & $*$ \\
\hline Lower middle 25 percent & 1.0 & 9.9 & & -3.2 & 13.2 & * \\
\hline Upper middle 25 percent & -0.2 & 8.6 & & 0.7 & 17.1 & \\
\hline Highest 25 percent & $t$ & 8.8 & & $t$ & 16.4 & \\
\hline \multicolumn{7}{|l|}{ Highest education attained by either parent } \\
\hline High school diploma or less & -1.0 & 9.2 & & -1.1 & 14.9 & \\
\hline Some postsecondary education & -2.1 & 8.1 & & -1.6 & 14.5 & \\
\hline Bachelor's or higher degree & $t$ & 10.2 & & $t$ & 16.1 & \\
\hline \multicolumn{7}{|l|}{ Attendance intensity through 2017} \\
\hline Always full time & $t$ & 9.8 & & $t$ & 15.8 & \\
\hline Always part time & -0.3 & 9.5 & & -4.3 & 11.5 & \\
\hline Mixed & -1.0 & 8.9 & & -0.2 & 15.6 & \\
\hline \multicolumn{7}{|l|}{ Ever had a stopout through 2017} \\
\hline No & $t$ & 9.2 & & $t$ & 15.9 & \\
\hline At least one time & 0.2 & 9.4 & & -2.3 & 13.6 & \\
\hline \multicolumn{7}{|l|}{ Ever changed major field through 2017} \\
\hline No & $\dagger$ & 9.6 & & $t$ & 16.3 & \\
\hline At least one time & -0.8 & 8.7 & & -1.4 & 14.9 & \\
\hline \multicolumn{7}{|c|}{ Ever transferred between institutions through 2017} \\
\hline No & $\dagger$ & 8.5 & & $t$ & 15.9 & \\
\hline At least one time & 2.8 & 11.4 & * & -1.8 & 14.1 & \\
\hline \multicolumn{7}{|l|}{ Number of STEM credits earned through 2017} \\
\hline $0-10$ & 1.5 & 10.5 & & -12.2 & 11.1 & $*$ \\
\hline$>10-20$ & -2.4 & 6.6 & & -11.1 & 12.2 & $*$ \\
\hline$>20-30$ & -1.9 & 7.2 & & -7.4 & 16.0 & $*$ \\
\hline$>30$ & + & 9.1 & & $t$ & 23.4 & \\
\hline \multicolumn{7}{|l|}{ Number of CTE credits earned through 2017} \\
\hline 0 & -2.8 & 9.0 & & -3.1 & 15.5 & \\
\hline$>0-10$ & -2.8 & 9.0 & & -4.0 & 14.6 & \\
\hline$>10-20$ & -0.7 & 11.0 & & -6.9 & 11.8 & $*$ \\
\hline$>20$ & $t$ & 11.8 & & + & 18.7 & \\
\hline
\end{tabular}




\begin{tabular}{|c|c|c|c|c|c|c|}
\hline \multicolumn{7}{|l|}{ Control and level of last institution } \\
\hline Public 2-year & $t$ & 8.8 & & $t$ & 17.4 & \\
\hline Public 4-year & 0.9 & 9.7 & & -3.3 & 14.1 & \\
\hline Private nonprofit 4-year & -0.2 & 8.6 & & -0.8 & 16.6 & \\
\hline Private for-profit & -0.3 & 8.5 & & -1.3 & 16.1 & \\
\hline Other & 7.0 & 15.8 & & -6.9 & 10.5 & \\
\hline \multicolumn{7}{|l|}{ Last major field as of 2017} \\
\hline$S T E M^{I}$ & $t$ & 11.9 & & $t$ & 20.2 & \\
\hline Business & -7.5 & 4.4 & $*$ & -1.5 & 18.7 & \\
\hline Education & -9.4 & 2.5 & $*$ & -13.8 & 6.4 & * \\
\hline Health care fields & -1.8 & 10.1 & & 5.0 & 25.2 & * \\
\hline Social/behavior sciences & -8.1 & 3.7 & $*$ & -9.0 & 11.2 & * \\
\hline Humanities & -4.4 & 7.4 & $*$ & -14.3 & 5.9 & * \\
\hline Personal and consumer services & -2.6 & 9.2 & & -6.7 & 13.5 & * \\
\hline Manufacturing etc. $^{2}$ & 3.6 & 15.5 & & -11.9 & 8.3 & $*$ \\
\hline Public, legal, and social services & -7.0 & 4.9 & $*$ & -12.3 & 7.9 & * \\
\hline Architecture, design, and applied arts & 2.4 & 14.3 & & 14.1 & 34.3 & * \\
\hline Communications & -3.3 & 8.6 & & -12.2 & 8.1 & * \\
\hline General studies & -1.5 & 10.4 & & -9.2 & 11.0 & * \\
\hline Undeclared or undecided & -0.9 & 11.0 & & -5.5 & 14.7 & $*$ \\
\hline \multicolumn{7}{|l|}{ Type of postsecondary credential earned as of 2017} \\
\hline No credential earned & 9.7 & 9.7 & & -16.3 & 7.2 & * \\
\hline Only certificate & 12.9 & 13.0 & $*$ & -19.3 & 4.3 & * \\
\hline Only associate's degree & 11.2 & 11.2 & $*$ & -15.4 & 8.2 & * \\
\hline Associate's degree plus certificate & 18.6 & 18.5 & $*$ & -10.8 & 12.7 & * \\
\hline Only bachelor's degree & + & 7.1 & & $t$ & 23.5 & \\
\hline Bachelor's degree plus certificate/associate's degree & 11.0 & 11.2 & & -2.9 & 20.6 & \\
\hline
\end{tabular}

controlling for other characteristics in the model, and this 10.7-percentage-points difference is statistically significant.

For ease of interpretation, table 12 also presents the predicted probability (PP) of achieving an outcome for each subgroup. Using "gender" as an example again, the predicted probability of female students working in STW jobs after college was 4.4 percent, while the predicted probability for male students was 15.1 percent. Thus, females' probability is 10.7 percentage points lower than males' probability (i.e., 15.1 $4.4=10.7$ ), corresponding to the ME. The following discussion uses the predicted probability for ease of understanding.

Characteristics associated with working in STW jobs in 2017. Based on the multivariate results, the outcome of working in a STW job after college was associated with gender, race/ethnicity, transferring schools, most recent major field of study, and the type of postsecondary credential earned. Men had a higher probability of working in STW jobs than women (15 percent vs. 4 percent), even after controlling for a range of other factors in the model. White students had a higher probability of working in STW jobs than Black students (10 percent vs. 6 percent). Those who last majored in a STEM field were more likely to work in a STW job (12 percent), compared with those who last majored in business; education; social/behavior sciences; humanities; and public, legal, and social services (2-7 percent). Students who had earned only certificates, only 
associate's degrees, or certificates plus associate's degrees had higher probabilities of working in STW jobs (11-19 percent), compared with those who had earned only bachelor's degrees ( 7 percent). Transferring schools was associated with a higher probability of working in STW jobs.

Characteristics associated with working in SPW jobs in 2017. Working in a SPW job after college was associated with gender, race/ethnicity, last major field, and the type of postsecondary credential earned, in addition to family income, STEM coursetaking, and CTE coursetaking. The following demographic groups were more likely than their comparison groups to work in a SPW job: men (compared to women), White students (compared to Black and Hispanic students), and those from high-income backgrounds (compared to those from low-income backgrounds). The relationship between STEM coursetaking and working in a SPW job appears to be linear: the more STEM credits students had earned in college, the more likely they were to pursue SPW jobs after college. The pattern for CTE credits was not as clear, although the relationship appears to be a U-shape (i.e., students who earned about 10-20 CTE credits tended to have a lower probability of pursuing SPW jobs than students at the low or high end of the CTE credit distribution). STEM majors, health care majors, and architecture/design/applied arts majors had a higher probability of working in SPW jobs relative to students who majored in other fields. Consistent with the definitions of the STW and SPW, the relationship of educational attainment with working in SPW jobs was contrary to that with working in STW jobs: students who had earned bachelor's degrees had a higher probability of working in SPW jobs than did their peers who had earned only sub baccalaureate credentials or those who had not earned any credential, net of other characteristics in the model.

\section{Conclusions}

Thus far, there is very little empirical research on the STW. This paper capitalized on recently available national data collected for the 2011-12 cohort of beginning postsecondary students to provide a close look at their transition into STW employment after college. The analyses yielded some insightful information that may provide a foundation for future research. The key findings and their implications for public polices, practices, and future research are discussed below.

- Despite lower educational attainment, STW workers fared better than workers in nontechnical jobs with respect to salary, access to workforce benefits, majorjob alignment, and job satisfaction. These advantages associated with STW employment were further confirmed by multivariate models that controlled for a wide range of factors that may affect employment outcomes.

- Despite positive employment outcomes and low credential requirements for entry, relatively few students pursued STW careers after college. Among 201112 beginning postsecondary students who entered the labor market after college, just 9 percent entered STW jobs. In contrast, 15 percent entered SPW jobs, and the vast majority, 75 percent, entered jobs that did not require high-level technical knowledge. 
- Less-than-4-year colleges and sub baccalaureate programs are the two most common paths to STW jobs. At least one-half of STW workers began their postsecondary education at a less-than-4-year institution and initially enrolled in a sub baccalaureate program. This finding highlights the important role that community colleges and sub baccalaureate programs play in developing the STW.

- Noteworthy percentages of STW workers in the BPS:12/17 cohort followed enrollment patterns that often slow the progress to postsecondary completion: 13 percent always attended school part time, 15 percent changed their majors two or more times, 32 percent interrupted their enrollment with a break of 5 or more months, and 31 percent transferred between schools. Future research needs to dig deeper into educational paths of STW workers, determining how many students follow a straight path to STW careers, how many wander around for a while before finding their way to STW jobs, and what factors lead to these different trajectories. Answers to these questions may help institutions support students with STW careers in mind to move through college more efficiently to reduce opportunity costs associated with delaying entry into the workforce.

- Historically, the underrepresentation of women, Black, Hispanic, and Native American people in STEM occupations has been a policy concern. STW occupations face the same issue: significantly fewer women than men and fewer Black workers than White workers pursued a STW career after college. Nevertheless, it is encouraging to see that post-college STW participation rates did not differ between Hispanic and White students or vary by students' family income and parental education.

- The majority of STW workers in the BPS:12/17 cohort were found in the following occupation families: installation, maintenance, and repair; production; healthcare; construction and extraction; and computer and mathematical occupations. Thus, one strategy to expand the number of students pursuing STW jobs is to encourage them to pursue majors in STEM, health care, and such technical fields as manufacturing, construction, repair, and transportation.

There are some weaknesses in this study, primarily due to limitations of BPS:12/17. First, because BPS:12/17 is not specifically designed to study STW issues, it does not have all variables relevant to STW jobs. Some variables that are potentially important to students' pursuit of STW careers (e.g., personal interest, career motivation, career counseling, institutional support, demand of STW workers in job markets) are not available in BPS:12/17, limiting the scope and depth of this work.

Second, informal training (e.g., professional licensure/certification programs) is another common path to a skilled technical occupation (NSB, 2019), but the BPS:12/17 data do not address such training. The role that informal training plays in entry into the STW is an important area for future research.

Third, this paper provides only a snapshot of STW participation in 2017 because BPS:12/17 has full occupation information only on respondents' 2017 jobs. As a result, the paper does not address the career trajectories of students and the dynamic process of STW participation after college (e.g., when students got their first job after college, 
whether their first job was a STW job, how long they held a STW job, and whether they switched from a STW job to a non-STW job and vice versa).

Fourth, the study sample used in the paper was somewhat skewed toward more socioeconomically and academically advantaged populations. This is largely due to the selection of a subsample of students who were working in 2017 and were more socioeconomically and academically advantaged relative to the unselected students. To avoid selection bias, future research needs to build the analysis on a population or representative sample of workers, not students. Focusing on workers instead of students would help yield a more accurate and complete picture of the STW in the entire U.S. workforce.

Finally, it is important to reiterate that this study is descriptive. Although the multivariate analysis in the last part of the paper controlled for a wide range of characteristics when looking at the outcome, it did not control for many other potential factors that may be associated with STW participation. While the multivariate results may inform future causal analyses, this study remains descriptive and does not purport to ratify any causal relationships.

\section{Acknowledgements}

The author would like to acknowledge Robin R. Henke, Susan Rotermund, and Joanna Wu of RTI International for their contributions to this paper. This study would not have been possible without generous financial support of RTI International.

\section{References}

Autor, D., Katz, L., \& Kearney, M. (2006). The polarization of the U.S. labor market. American Economic Review Papers and Proceedings, 96(2), 189-194. https://doi.org/10.1257/000282806777212620

Borooah, V. K. (2001). Logit and probit: Ordered and multinomial models. SAGE Publications.

Chen X., Lauff, E., Arbeit, C. A., Henke, R., Skomsvold, P., \& Hufford, J. (2017). Early millennials: The sophomore class of 2002 a decade later. U.S. Department of Education, National Center for Education Statistics. https://nces.ed.gov/pubs2017/2017437.pdf

Chen, X., \& Rotermund, S. (2020). Entering the skilled technical workforce after college. RTI Press. https://doi.org/10.3768/rtipress.2020.rb.0024.2004

Holzer, H. (2015). Job market polarization and U.S. worker skills: A tale of two middles. Brookings Institution. https://www.brookings.edu/wpcontent/uploads/2016/06/polarization_jobs_policy_holzer.pdf

Levesque, K., Laird, J., Hensley, E., Choy, S. P., Cataldi, E. F., \& Hudson, L. (2008). Career and technical education in the United States: 1990 to 2005. U.S. Department of Education, National Center for Education Statistics. https://nces.ed.gov/pubs2008/2008035.pdf

National Research Council. (2014). Opportunities for the gulf research program: Middle-skilled workforce needs. The National Academies Press. https://doi.org/10.17226/18980

National Science Board (NSB). (2015). Revisiting the STEM workforce: A companion to science and engineering indicators 2014. National Science Foundation. https://www.nsf.gov/pubs/2015/nsb201510/nsb201510.pdf 
National Science Board (NSB). (2018a). Science and engineering indicators 2018. National Science Foundation. https://www.nsf.gov/statistics/2018/nsb20181/assets/nsb20181.pdf

National Science Board (NSB). (2018b). Our nation's future competitiveness relies on building a STEM-capable U.S. workforce: A policy companion statement to science and engineering indicators 2018. National Science Foundation. https://www.nsf.gov/pubs/2018/nsb20187/nsb20187.pdf

National Science Board (NSB). (2019). The skilled technical workforce crafting America's science \& engineering enterprise. National Science Foundation. https://www.nsf.gov/nsb/publications/2019/nsb201923.pdf

National Science Board (NSB). (2020). Science and engineering indicators 2020: The state of U.S. science \& engineering 2020. National Science Foundation. https://ncses.nsf.gov/pubs/nsb20201

Pretlow, J., Jackson, D., \& Bryan, M. (2020). A 2017 follow-up: Six-year persistence and attainment at any institution for 2011-12 first-time postsecondary students. U.S. Department of Education, National Center for Education Statistics. https://nces.ed.gov/pubs2020/2020238.pdf

Rothwell, J. (2013). The hidden STEM economy. Brookings Institution. https://www.brookings.edu/wpcontent/uploads/2016/06/TheHiddenSTEMEconomy610.pdf

Rothwell, J. (2016). Defining skilled technical work. Issues in Science and Technology, 33(1), 47-51. https://doi.org/10.2139/ssrn.2709141 